メタヒューリスティクスを用いたCGS 及び複数蓄エネルギー設備を含む エネルギーシステムの多目的非線形最適化手法の開発

\title{
DEVELOPMENT OF A METAHEURISTIC NONLINEAR MULTI-OBJECTIVE OPTIMIZATION METHOD FOR OPERATING ENERGY SYSTEMS INCLUDING CGSAND ENERGY STORAGE SYSTEMS
}

\author{
池田 伸太郎*，大 岡 龍 三** \\ Shintaro IKEDA and Ryozo OOKA
}

\begin{abstract}
Co-generation systems (CGS) and energy storage equipment, such as batteries and thermal energy storage (TES), have become increasingly important recently for improving energy efficiency and for adjusting or reducing peak loads of energy systems. However, optimization of operating schedules of such energy storage equipment is difficult due to its parameter dependency. In addition, a nonlinear characteristics of recent heat-source machines have made the problem more difficult. Therefore, we applied an efficient optimization method, $\varepsilon \mathrm{DE}$ (epsilon constrained differential evolution) for single objective optimization, to minimize operating costs. Moreover, we proposed $\varepsilon$ MODE (epsilon constrained multi-objective differential evolution) to solve the complex trade-off problem (costs vs primary energy consumption). Each result showed that these methods could provide the optimum solution in a practical time, even if the problem had a lot of decision variables that were nonlinear. In particular, $\varepsilon$ MODE could carry out a lot of non-dominated solutions without concentrating on a certain position and generating dominated solutions.
\end{abstract}

Keywords : CGS, Battery, Thermal Energy Storage, Energy System Optimization, Metaheuristics CGS，蓄電池，蓄熱槽，エネルギーシステム最適化，メタヒューリスティクス

1. はじめに

近年、コージェネレーションシステム (CGS)や蓄熱槽 (TES: Thermal energy storage)等の蓄エネ設備が注目されて久しい。加え て、熱源機の効率的な運転を可能とするインバータ技術等も普及し ている。しかし、それらの運用を統合的に最適化することは容易で ない。その主な理由として、1）CGS 導入による運転計画の選択肢 (操作変数)の増加、2）インバータ技術や流量、温度計算に用いる非 線形形状、3）蓄エネ設備最適化における変数間依存性、以上 3 点が 挙げられる。1)は、CGS からの排熱を熱源機や給湯需要などに供給 するルートの選択肢が拡大し、最適化問題がより大規模化・複雑化 することを意味する。CGS を含む大規模システムに関する研究とし て代表的なものでは伊東の一連の研究 ${ }^{1}$ が、近年では 2 棟の建物を 対象に一方の CGS からの電力・排熱の融通を考慮した石田ら 2)や、 それを拡張し 2 棟それぞれの CGS の共有及び売電を含めた最適運 用を検討した Kayo ら 3)、地域冷暖房を対象に解析範囲を街区レベ ルまで発展させた Buoro ら 4)の研究等がある。しかし、上記の研究 は蓄熱槽や蓄電池を考慮しておらず、蓄エネ設備の将来性を鑑みれ ばそれらを考慮した研究が期待される。2)は、インバータ技術等に よる熱源機等の非線形特性がもたらす最適化問題の難化を意味する。 前述の伊東 ${ }^{1)}$ 、Buoro ら ${ }^{4)}$ の研究を始め、広く適用されている混合
整数線形計画法(MILP: Mixed-integer linear programming)は、非 線形関数を線形化することにより本来複雑な目的関数及び制約条件 を簡易なモデルとして扱うことを目的としており、その結果、大規 模なシステムや複数年解析などが可能となった 5),6)。線形化による アプローチは強力な手法であるが、現在、インバータ技術が普及し 冷却水温度や流量などによって元々非線形な性能曲線の形状が更に 連続的に変化するなど、複雑な非線形特性がシステムの一次エネル ギー消費量等の増減に与える影響は少なくない。従って、本来なら ば非線形関数をそのまま処理することが望ましいと考える。また、 Facci ら 7)が CHCP (Combined heat power and cooling)の運用最適 化に用いた動的計画法(DP: Dynamic programming)は、非線形形状 を扱うことができ、全探查と比較すると効率的な探索が可能である が、筆者らは既報 8)にて DP の計算時間に関して言及しており、そ れに対して、高精度を維持したまま高速な計算が可能な「メタヒュ ーリスティクス」という最適化手法を提案している。ここで、メタ ヒューリスティクスとは遺伝的アルゴリズム (GA：Genetic algorithm)に代表される反復学習的な手法の総称である。3)では、 蓄エネ設備がエネルギーを貯める時間と使う時間とが異なることに よる最適化問題の難化を意味する。具体的には、各時刻における熱 源出力の組合せ最適化のみならず、解析期間全体での組合せ最適化
* 東京大学大学院工学系研究科建築学専攻 博士課程 日本学術振興会特別研究員 DC

** 東京大学生産技術研究所 教授·博士 (工学)
Ph.D. Student, Dept. of Architecture, Graduate School of Engineering, The University of Tokyo. JSPS Research Fellow

Prof., Institute of Industrial Science, The University of Tokyo, Ph.D. 
が必要となることから、最適化問題における変数間依存性が強くな る。ここで、変数間依存性とは、多変数関数最適化の際に、2 つ以 上の変数を同時に変化させなければ効率的な探索が出来ないような 特性のことで、変数間依存性が強い問題ほど高難度な最適化問題と 換言出来る。従って、蓄エネ設備を含むか否かによって最適化のア プローチ自体が異なる上、最適化問題としての難度も上がるため、 より効率的な手法が必要とされる。

以上より、冷熱・温熱の供給ルート及び蓄エネ設備導入により変 数の増加及び探索難度が上昇した場合でも非線形のまま高速に最適 解の探索が可能な手法の必要性は将来的にも高いものと筆者らは認 識している。そこで、上記の 3 点を満たす解法として、前述のメタ ヒューリスティクス、具体的には、Takahama ら 9)によって提案さ れた $\varepsilon \mathrm{DE}$ (Epsilon constrained differential evolution)を採用した。 その理由として、効率的な制約条件処理能力が挙げられる。メタヒ ューリスティクスは関数形状を問わない汎用的な手法である一方で、 元来その開発過程では非制約問題を対象としており、制約条件付き の問題では適切な解法を用いなければ実行可能解自体が見つからな い可能性も否定できない。そこで、どのように制約条件を扱うかに 関しては「制約条件処理手法」と分類され、盛しに研究が行われて いる。その中でも、 $\varepsilon \mathrm{DE}$ は収束性等で優れた結果を示しており 10)、 本研究で扱うような複雑な問題への適用に值する。そこで、本研究 の第一の目的として、 $\varepsilon \mathrm{DE}$ を適用することにより、複雑なエネルギ ーシステムにおける単目的最適化計算の実現可能性を示す。

更に、現実における運用コスト削減の重要性はもちろん、一次エ ネルギー消費量の削減等も取り組むべき課題であると考え、本研究 では上記の $\varepsilon \mathrm{DE} に 、 A l i ~ ら ~{ }^{11)}$ にって提案された高性能な多目的最 適化手法である MODEA (Multi-objective differential evolution

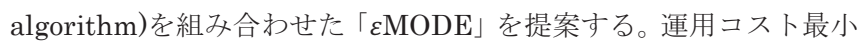
化と一次エネルギー消費量最小化を対象とする多目的最適化への桩 張に加えて、単目的時との最適運用の差異及び多目的最適化として の性能を示すことで本手法の妥当性を示す。

なお、本報で対象とする非線形最適化問題は、計算機科学におけ る NP 困難と呼ばれる多項式時間で真の最適解を得ることは出来な い問題と認識されている。その問題に対して、メタヒューリスティ クスでは確率論的探索によって解を得るため、厳密には準最適解と いう位置づけになるが、本分野では慣例的に最適解という言葉が使 用されているため、本報でも最適解という表現を使う。

\section{2. 解析条件}

\section{1 需要データ及び変動型電気料金単価}

本研究では、冷房需要、一般電力需要(照明や $\mathrm{OA}$ 機器等)の他に 給湯需要が十分得られる用途の建物として延床面積 $20000 \mathrm{~m}^{2}$ の木 テルを想定した。解析期間は 8 月代表日の 24 時間、解析ステップ は 1 時間とし、各種需要はコージェネレーション評価プログラム (CASCADE III) ${ }^{12)}$ のデフォルトデータを参照した。太陽光発電(PV: Photovoltaics)の発電量計算に用いる日射量及び外気温は拡張 AMeDAS 東京標準気象データ(2005)老使用し、太陽赤緯(14.298)及 び均時差(-0.07797)は平成 24 年度理科年表 13)を参照している。各時 刻の電気料金単価は、著者らの既報 8 ) 従い、需要変動に沿って変 化するリアルタイムプライシング(RP: Real-time pricing)を想定し
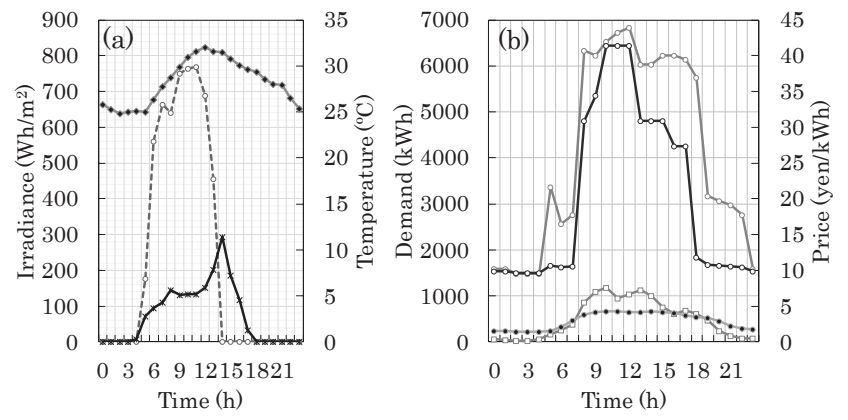

-o- Direct normal solar irradiance $\left(\mathrm{W} / \mathrm{m}^{2}\right)$

* Horizontal diffuse irradiance $\left(\mathrm{W} / \mathrm{m}^{2}\right)$

$-\infty$ Cooling demand $(\mathrm{kWh})$

$\rightarrow$ Outdoor temperature $\left({ }^{\circ} \mathrm{C}\right)$ $\rightarrow-$ Hot water demand $(\mathrm{kWh})$

$\sim$ Price of purchased electricity (yen/kWh)

Fig. 1 Outdoor condition, demand curves, and dynamic pricing, (a) Outdoor condition, (b) Demand curves and price

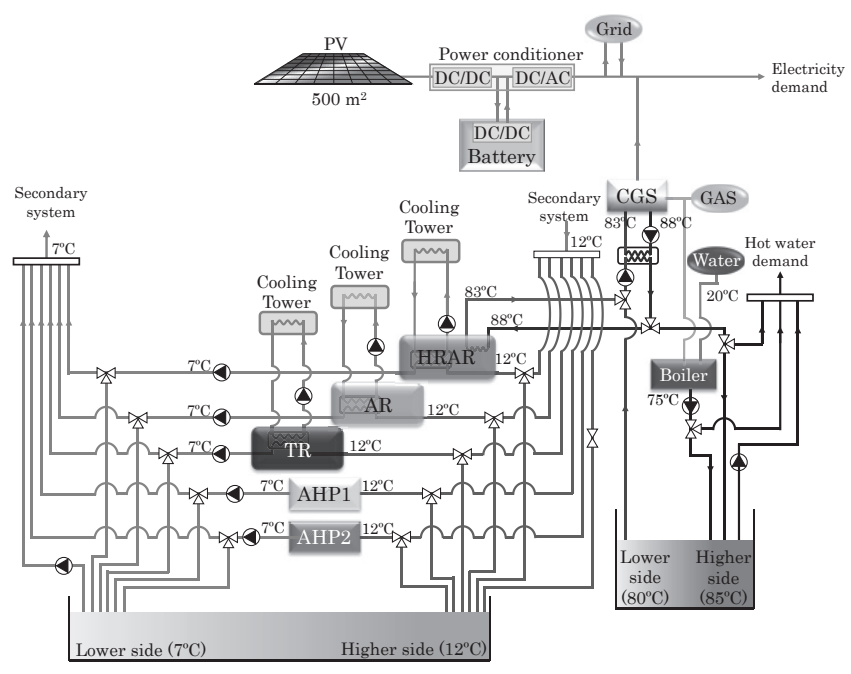

Fig. 2 Piping flow of energy system

た。Fig.1 に外界条件・需要及び電気料金単価を示す。なお、各種需 要はタイムステップ 1 時間における值とし単位を $\mathrm{kWh}$ としている。 これ以降、熱源出力なども 1 時間の出力として単位を $\mathrm{kWh}$ とする。

\section{2 エネルギーシステム}

蓄熱槽(TES: Thermal energy storage)は空調用(TES-C) と給湯用 $(\mathrm{TES}-\mathrm{H})$ の 2 種類を想定し、容量はそれぞれ $10000 \mathrm{kWh}, 1200 \mathrm{kWh}$ と仮定した。これは、冷房・給湯需要の日積算值の $10 \%$ を賄う值で ある。熱源機器は、ターボ冷凍機(TR: Turbo refrigerator)×1、空気 熱源ヒートポンプチラー(AHP: Air-source heat pump)×2、吸収式 冷凍機(AR: Absorption refrigerator) $\times 1$ 、排熱回収型吸収式冷凍機 (HRAR: Heat recovered AR)×1、CGS×1、バックアップボイラ $(B B:$ Backup boiler)×1 を想定した(Fig.2)。各熱源機と TES の運転方式 は、1）蓄熱運転 : 熱源機による熱を TES 一蓄熱するのみ、2）熱源 機単独運転：熱源機から直接冷房／給湯需要へ熱を供給する、3) TES 単独運転：TESの放熱のみによって需要を賄う、4）追掛け運 転 : 蓄熱槽からの放熱および熱源機からの需要への直接供給による 運転、以上を考慮している。各機器の詳細は Table 1 に示寸通りで ある。 
本研究では、熱源機からの出力や TES の蓄放熱をモデル化する 際に、熱量ベース $(\mathrm{kW}, \mathrm{kWh})$ での計算を行っており、簡易化の為に 冷水温度及び温水温度は Fig. 2 に示した数值に固定している。一方 で、熱源の部分負荷運転を考慮するために、流量は変流量方式を採 用した。また、冷却塔を有する熱源 (TR, AR, HRAR)に関しては、冷 却水温度が運転効率に大きく影響するため、熱源一冷却塔間の泠却 水温度及び冷却水流量を両方とも変動させている。ただし、同時に 変化させると值が一意的に定まらないため、始めに冷却水流量を定 格とし冷却水温度を変化させ、冷却水入口温度と出口温度の差が $3^{\circ} \mathrm{C}$ 以下になった場合にのみ冷却水流量を変化(減少)させた。冷却水 温度等の計算には後述する熱源機器の特性と同じく LCEM tool ${ }^{14)}$ 参照している。著者の既報 ${ }^{15}$ ) と同様に、外気乾球温度と相対湿度か ら水蒸気分圧等を求め、最終的に外気湿球温度を算出し、冷却塔の 冷却水出口温度を計算する。その出口温度を熱源の冷却水入口温度 とし出力との関係から熱源からの泠却水出口温度を計算し、冷却塔 に戻す。冷却塔ファンは定格冷却水量を基準に $50 \%$ を下限、110\%を 上限として連続的に運転できるものと仮定する。

上記の熱源機器等に加えて、蓄電池(B)及び $\mathrm{PV}$ も考慮した。 $\mathrm{PV}$ からの電力分配ルートは、1）蓄電池への供給、2）一般電力需要へ の供給、3）売電、の 3 通りを想定しており、蓄電池は、1）一般電 力需要への供給、2) 売電の 2 通りを想定した。また、一次エネルギ 一消費量等の算定に利用する係数は次のように設定した。1）運用コ スト (電気): RP、（ガス): $\left.87.2 \mathrm{yen} / \mathrm{m}^{3} 、 2\right)$ 一次エネルギー消費量(電 気): $9.97 \mathrm{MJ} / \mathrm{kWh}$ 、(ガス): $\left.45.0 \mathrm{MJ} / \mathrm{m}^{3} 、 3\right) \mathrm{CO}_{2}$ 排出量(電気): 0.512 $\mathrm{kg}-\mathrm{CO}_{2} / \mathrm{kWh}$ 、(ガス): $2.29 \mathrm{~kg}-\mathrm{CO}_{2} / \mathrm{m}^{3}$ である。

\section{3 熱源機器の特性}

ポンプ類を含む熱源機の特性は LCEM tool を参照している。従 って、BB を除く全ての熱源機は非線形形状の特性を持つ(Fig.3)。 Fig. 3(a)は定格燃料消費量に対する部分負荷時の燃料消費率を示し ている。ただし、HRAR は排熱投入の有無によって燃料消費率が変 化するため、Fig3（a）には定格值まで排熱を投入した場合の特性曲 線を示した。Fig.3 (b)には、単位エネルギー $(\mathrm{MJ})$ 投入当たりの生成 熱量 $(\mathrm{MJ})$ を示した。意味合いとしては電気主体熱源の COP と同様 であるが、一次エネルギー基準の効率であることに注意されたい。 投入エネルギーには前述の一次エネルギー換算係数を、生成熱量に 関しては 1 時間生成するものとし、 $1 \mathrm{kWh}=3.6 \mathrm{MJ}$ とした。HRAR は投入エネルギーとして電気、ガス、排熱を考慮した。Fig.3の各熱 源機器の特性曲線は、冷却水温度 $32^{\circ} \mathrm{C}$ 、外気温 $25^{\circ} \mathrm{C}$ を想定した際 の形状であり、それぞれが変化することによって連続的に関数形状 も変化する。従って、特に Fig. 3 (b)に示した効率の順位が、最適化 計算の際にそのまま利用できるわけではないことに注意されたい。 なお、CGS は LCEM ッールに収録されていない為、機器容量や効 率等は既往文献 16)を参照し、特性曲線は次のように別途モデル化を 行なった。文献 17)を参考に、定格運転時、稼働率 $75 \%$ 時、同 $50 \%$ 時 の発電効率及び排熱効率をプロットし、文献 18)を参考にそれぞれ二 次曲線で近似することで効率曲線を作成した(Fig.4)。

\section{3. 定式化と最適化手法}

\section{1 定式化}

本研究では 24 時間の運用コスト最小化を目的として最適化計算
Table 1 Information of energy systems

\begin{tabular}{|c|c|c|}
\hline $\begin{array}{l}\text { Absorption } \\
\text { refrigerator } \\
\text { (AR) }\end{array}$ & $\begin{array}{l}\text { Capacity } \\
\text { Rate gas consumption } \\
\text { Rate electric consumption }\end{array}$ & $\begin{array}{c}1500 \mathrm{~kW} \\
86.8 \mathrm{~m}^{3} / \mathrm{h} \\
15 \mathrm{~kW}\end{array}$ \\
\hline $\begin{array}{r}\text { Heat re } \\
\text { AR }(H\end{array}$ & $\begin{array}{l}\text { Capacity } \\
\text { Rate gas consumption } \\
\text { Rate electric consumption } \\
\text { Rate amount of recovered heat }\end{array}$ & $\begin{array}{c}1000 \mathrm{~kW} \\
59.4 \mathrm{~m}^{3} / \mathrm{h} \\
9.85 \mathrm{~kW} \\
307 \mathrm{~kW}\end{array}$ \\
\hline $\begin{array}{l}\text { Air-source heat } \\
\text { pump 1 (AHP1) }\end{array}$ & $\begin{array}{l}\text { Capacity } \\
\text { Rate electric consumption }\end{array}$ & $\begin{array}{c}550 \mathrm{~kW} \\
153.4 \mathrm{~kW}\end{array}$ \\
\hline $\begin{array}{l}\text { Air-source heat } \\
\text { pump 2 (AHP2) }\end{array}$ & $\begin{array}{l}\text { Capacity } \\
\text { Rate electric consumption }\end{array}$ & $\begin{array}{c}500 \mathrm{~kW} \\
139.5 \mathrm{~kW} \\
\end{array}$ \\
\hline $\begin{array}{l}\text { Co-generation } \\
\text { system (CGS) }\end{array}$ & $\begin{array}{l}\text { ty } \\
\text { mount of recovered heat } \\
\text { as consumption }\end{array}$ & $\begin{array}{c}363 \mathrm{~kW} \\
300 \mathrm{~kW} \\
71.3 \mathrm{~m}^{3} / \mathrm{h}\end{array}$ \\
\hline $\begin{array}{l}\text { Backup boiler } \\
\text { (BB) }\end{array}$ & $\begin{array}{l}\text { Capacity } \\
\text { Rate gas consumption } \\
\text { Rate electric consumption }\end{array}$ & $\begin{array}{l}750 \mathrm{~kW} \\
73 \mathrm{~m}^{3} / \mathrm{h} \\
2.1 \mathrm{~kW} \\
\end{array}$ \\
\hline $\begin{array}{c}\text { Thermal energy } \\
\text { storage - cooling } \\
\text { demand (TES- } \\
\text { C) }\end{array}$ & $\begin{array}{l}\text { Capacity } \\
\text { Charging/discharging efficiency } \\
\text { Self heat loss rate }\end{array}$ & $\begin{array}{c}10000 \mathrm{kWh} \\
100 \% / \mathrm{cycl} \\
5 \% / \text { day } \\
(0.2 \% / \mathrm{h})\end{array}$ \\
\hline $\begin{array}{c}\text { Thermal energy } \\
\text { storage }- \text { hot } \\
\text { water demand } \\
\text { (TES-H) } \\
\end{array}$ & $\begin{array}{l}\text { Capacity } \\
\text { Charging/discharging efficiency } \\
\text { Self heat loss rate }\end{array}$ & $\begin{array}{c}1200 \mathrm{kWh} \\
100 \% / \text { cycle } \\
5 \% / \text { day } \\
(0.2 \% / \mathrm{h})\end{array}$ \\
\hline Battery (B) & $\begin{array}{l}\text { Capacity } \\
\text { Maximum charge/discharge } \\
\text { Charging/discharging efficiency } \\
\text { Self-discharge rate }\end{array}$ & $\begin{array}{c}500 \mathrm{kWh} \\
100 \mathrm{~kW} \\
81 \% / \text { cycle } \\
0 \% / \text { day } \\
\end{array}$ \\
\hline $\begin{array}{c}\text { Photovoltaic } \\
\text { device (PV) }\end{array}$ & $\begin{array}{l}\text { Area } \\
\text { Conversion efficiency } \\
\text { Conversion efficiency of power } \\
\text { conditioner }\end{array}$ & $\begin{array}{c}1000 \mathrm{~m}^{2} \\
13 \% \\
97 \%\end{array}$ \\
\hline
\end{tabular}
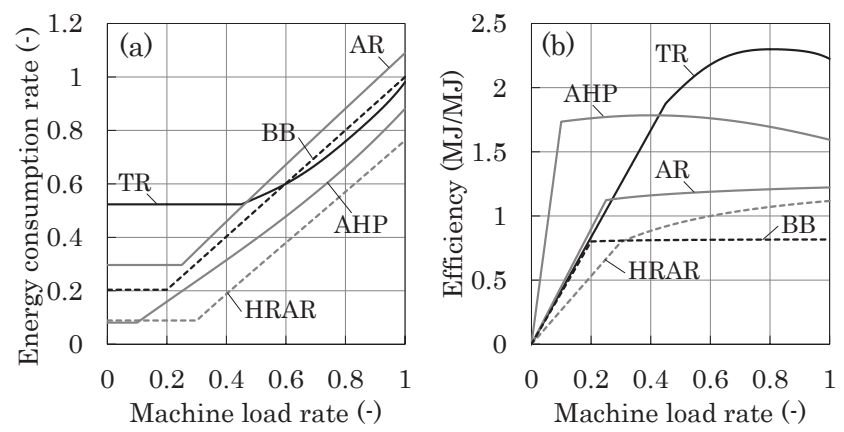

Fig. 3 Characteristics of heat source machines,

(a) Partial load rate - Energy consumption rate,

(b) Partial load rate - Machine efficiency

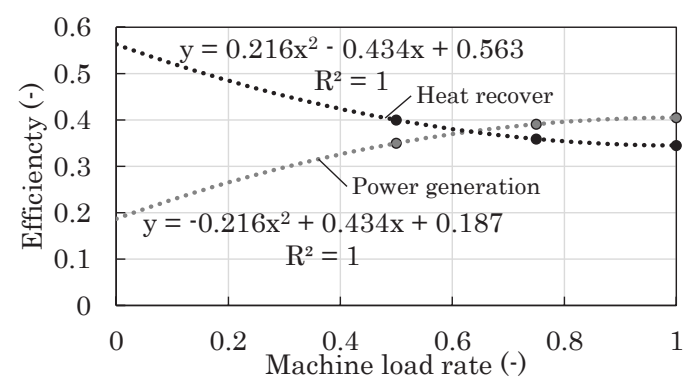

Fig. 4 Characteristics of CGS 
を行なった。目的関数は次の式(1)で表される。

$$
\begin{aligned}
& \min f \\
& =\sum_{t=1}^{\text {TimeH }}\left\{c _ { \text { elec-buy } } ^ { t } \left(D_{\text {elec }}^{t}+a c d^{t}-B t o D_{\text {elec }}^{t}-P V \text { to } D_{\text {elec }}^{t}\right.\right. \\
& \left.\left.-C G S t o D_{\text {elec }}^{t}\right)-c_{\text {elec-sold }}^{t}\left(B t o G^{t}+P V t o G^{t}\right)\right\} \\
& +\sum_{t=1}^{T i m e H} c_{\text {elec-buy }}^{t}\left(E C_{T E S-C}^{t}+E C_{T R}^{t}+E C_{A R}^{t}+E C_{H R A R}^{t}+E C_{A H P 1}^{t}\right. \\
& \left.+E C_{A H P 2}^{t}+E C_{C G S}^{t}+E C_{B B}^{t}\right) \\
& +\sum_{t=1}^{T i m e H} c_{\text {gas-buy }}^{t}\left(G C_{A R}^{t}+G C_{H R A R}^{t}+G C_{C G S}^{t}+G C_{B B}^{t}\right)
\end{aligned}
$$

TimeH は解析期間 $(24 \mathrm{~h}) 、 c_{\circ \circ-\Delta \Delta}^{t}$ は時刻 $t$ の elec - buyが買電単価 (yen/kWh)、elec - soldが売電単価、gas - buyがガス単価 $\left(\mathrm{yen} / \mathrm{m}^{3}\right)$ である。 $D_{\text {elec }}^{t}$ は一般電力需要 $(\mathrm{kWh}) 、 a c d^{t}$ は蓄電量 $(\mathrm{kWh}) 、 X t o Y$ は機 器 $X$ から機器 $Y$ もくは需要 $/$ グリッド $(\mathrm{G})$ への分配電力 $(\mathrm{kWh}) 、 E C_{\Delta}^{t}$ は一次ポンプ等の周辺機器を含む機器 $\triangle$ の電力消費量 $(\mathrm{kWh}) 、 G C_{\Delta}^{t}$ は機器 $\Delta$ のガス消費量 $\left(\mathrm{m}^{3} / \mathrm{h}\right)$ である。制約条件は下記の通りである。 $\mid$ acd $^{t} \mid \leq$ Maxacd

$\left\{\begin{array}{c}P V \text { to } B^{t}=0 \quad\left(a c d^{t} \geq 0: \text { 放電 }\right) \\ P V t o B^{t} \leq\left|a c d^{t}\right|\left(a c d^{t}<0 \text { : 蓄電 }\right)\end{array}\right.$

$$
\left\{\begin{array}{c}
\text { Bto } D_{\text {elec }}^{t}+P V t o D_{\text {elec }}^{t}+C G S t o D_{\text {elec }}^{t}\left(\text { acd }^{t} \geq 0\right) \\
\leq D_{\text {elec }}^{t} \\
\text { PVto } B^{t}+P V \text { to } D_{\text {elec }}^{t}+C G S t o D_{\text {elec }}^{t}\left(\text { acd }^{t}<0\right) \\
\leq D_{\text {elec }}^{t}+\left|a c d^{t}\right|
\end{array}\right.
$$

$0 \leq P_{T R}^{t} \leq \operatorname{Max} P_{T R}$

$0 \leq P_{B B}^{t} \leq \operatorname{Max} P_{B B}$

式(2)は蓄電池の最大蓄放電量 $(\mathrm{kWh})$ に関する制約である。式(3)は PV と蓄電池の稼働状況に関する制約であり、蓄電池が放電の時は、 PVから蓄電池への電力供給は 0 に、蓄電池が蓄電しているときは、 その蓄電量以下になるように設定する。なお、PV からの電力供給 はPVが発電しているときのみ正の值をとり、それ以外の時間帯で は 0 を初期值として与えている。各ルートへの電力供給割合は後述 の操作変数值から決定する。式(4)は一般電力需要に関する制約であ り、蓄電池 $(\mathrm{B}) 、 \mathrm{PV} 、 \mathrm{CGS}$ からの電力供給量が一般電力需要を上回 らないようにする。これは、仮に式(4)を設定しない場合、需要への 分配ルートから得られる合計電力が需要を上回ることが可能となり、 その差分を売電電力とすることが考えられるが、そのようにすると どの機器からの電力がグリッドに売電されたのかが決定できない。 従って、式(4)を設定することによって各ルートを重複させず各機器 からの電力の流れを明らかにすることが可能となる。操作変数は、 14 種類 24 時間分の計 336 変数 $\in[0,1]$ であり次に示す通りである。 1）定格蓄電容量に対する蓄電率、2）放電量分配率：蓄電池 $\rightarrow$ グリ ツド、3）放電量分配率：蓄電池 $\rightarrow$ 一般電力需要、4) PV 発電電力分 配率: PV $\rightarrow$ グリッド、5) PV 発電電力分配率: PV $\rightarrow$ 蓄電池、6) PV 発 電電力分配率: $\mathrm{PV} \rightarrow$ 一般電力需要、7）空調用蓄熱槽，定格蓄熱量に 対する蓄熱率、8）給湯用蓄熱槽，定格蓄熱量に対する蓄熱率、9) $\mathrm{AR}$ 部分負荷率、10) HRAR 部分負荷率、11）AHP1 部分負荷率、12） $\mathrm{AHP} 2$ 部分負荷率、13) CGS 発電率、14) CGS $\rightarrow \mathrm{HRAR}$ 出力分配率、 以上である。なお、上記に含まれていない $\mathrm{TR}$ 及び BB の出力は、 蓄放熱量及びその他熱源機器の出力と需要のバランス式から求めて
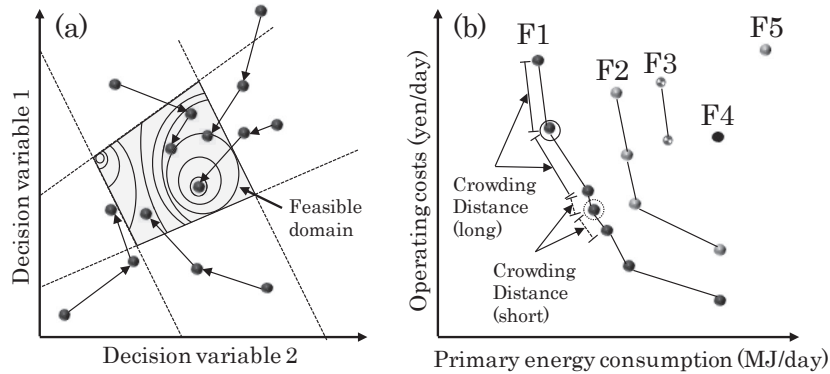

Fig. 5 Searching process of $\varepsilon \mathrm{DE}$ and $\varepsilon \mathrm{MODE}$, (a) Epsilon constraint method of $\varepsilon \mathrm{DE}$, (b) NDS and CDA of $\varepsilon \mathrm{MODE}$
おり、この定式化操作により制約条件から等式条件を排除している。 また、式(5)及び式(6)は TR と BB の出力に関する制約であり、それ ぞれ TR の最大出力 $\operatorname{Max}_{T R}$ 以下、 $\mathrm{BB}$ の最大出力MaxP $P_{B B}$ 以下に制限 することを条件としている。

\section{2 最適化手法}

3.2.1 $\varepsilon \mathrm{DE}$

一般的に最適化問題では目的関数の景観は事前に知り得ないため、 特に非線形最適化では、局所解が複数存在する「多峰性関数」を想 定した場合でも十分解析可能な汎用性の高い最適化手法を適用する 必要がある。そこで本研究では、筆者らの既報 8)において有効性を 示したメタヒューリスティクスの中でも、制約条件を効率的に処理 する手法として Takahama ら 9) が提案した $\varepsilon$ DE (epsilon constrained differential evolution)を採用した。 $\varepsilon \mathrm{DE}$ は制約条件を どの程度逸脱しているかを表す制約逸脱度 $\varphi$ を式(7)で定義し、式(8) によって $\varphi$ と目的関数值 $f$ の最小化を図る手法である。

$$
\begin{gathered}
\varphi\left(x_{i}\right)=\sum_{j} \max \left\{0, g_{j}\left(x_{j}\right)\right\}^{p}+\sum_{j}\left|h_{j}\left(x_{i}\right)\right|^{p} \\
\left(f_{1}, \varphi_{1}\right)<_{\varepsilon}\left(f_{2}, \varphi_{2}\right) \Leftrightarrow\left\{\begin{array}{l}
f_{1}<f_{2} \text { if } \varphi_{1}, \varphi_{2} \leq \varepsilon \\
f_{1}<f_{2} \text { if } \varphi_{1}=\varphi_{2} \\
\varphi_{1}<\varphi_{2} \text { otherwise }
\end{array}\right.
\end{gathered}
$$

ここで、 $p$ は正数であり、通常 1 に設定する。式(7)は墦目の個体 $\left(x_{i}\right)$ の制約逸脱度 $\varphi\left(x_{i}\right)$ で、不等式制約式 $g_{j}\left(x_{i}\right)$ の逸脱度と等式制約式 $h_{j}\left(x_{i}\right)$ の逸脱度の合計を示している。式(8)は個体同士の比較方法を 示している。 $\varepsilon \mathrm{DE}$ ではどの程度逸脱を許容するかを示す $\varepsilon$ を指数 関数的に減少させ、事前に定めた世代数で 0 に設定する。 $\varepsilon$ が 0 の 時、制約逸脱は全く許容されないが、探索当初からその条件では制 約条件が厳しい問題において実行可能解が見つからずに探索が終了 する可能性がある。そこで、探索当初は $\varepsilon$ の值に余裕を持たせ、世 代数が進むにつれて減少させるという方針をとる。前世代の個体の 逸脱度 $\varphi_{1}$ と新世代の個体の逸脱度 $\varphi_{2}$ と $\varepsilon$ を式(8)のように比較し、 その大小関係により、個体の入れ替えを目的関数值 $f_{1}, f_{2}$ で比較する のか、逸脱度で比較するのかを決定する。世代が進むと $\varepsilon$ が減少し 制約逸脱条件が厳しくなるため、Fig. 5(a)に示寸ように個体は徐々 に実行可能領域内に入ってくる。本研究では個体数を 100 個、世代 数を 10000 世代としており、5000世代において $=0$ とした。

\section{$3.2 .2 \varepsilon \mathrm{MODE}$}

本研究では多目的最適化も同時に検討した。制約条件の処理手法 
として優れている $\varepsilon \mathrm{DE}$ を多目的に拡張する為、Ali ら ${ }^{11}$ が提案した MODEA(Multi-objective differential evolution algorithm) と $\varepsilon \mathrm{DE}$

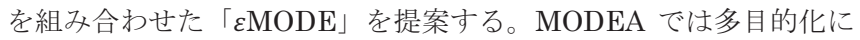
おける多様性確保策として、Deb ら 19)が提案した Non-dominated sorting (NDS) と Crowding distance assignment (CDA)をDE に適 用しており、パレート最適解が既知のテスト関数にて良好な結果を 示している。NDS や CDA 等の詳細は文献 11)及び 19)に記載され ているが、概要は以下のとおりである。

Non-dominated sorting とは Fig. 5(b)に示すように、全個体に対 して、パレート解を構成する個体毎に F1，F2,...(FRank という)と グループ化し、F1 から順にランキング形式で次世代一継承させる。 通常、DE では世代 $g$ の $i$ 番目の個体 $x_{i}^{g}$ と次世代の $x_{i}^{g+1}$ の目的関数值 を比較し良いほうを残寸といういわゆる離散世代モデルを用いてい るのに対し、Deb らやAli らの手法では最終的な世代間移行時に、 世代 $g$ の全個体と世代 $g+1$ 全個体を総比較して上位個体群を継承 する方針(アーカイブ方式)をとっている。しかし、 $\varepsilon$ MODE ではまず $\varphi$ の単目的最小化を行ない実行可能解を生成しつつ、NDSにより多 目的化を行なう為、Ali らの手法では $\varphi$ を最小化する途中で、ある特 定の座標を持つ個体が急速に増加し局所解に至ってしまう。そこで、 本研究では、 $\varphi$ の最小化時、つまり $\varepsilon$ 制約法の作用時は通常の離散世 代モデルを使用し、実行可能個体に対してのみ MODEA アルゴリズ ムを適用する。次に、CDA とは、同一FRank 内の個体群に対して、 各目的関数值の最小值を持つ個体(各軸の端の個体)を除く、個体に 対して、個体同士が離れていればいるほど評価が高くなるようにラ ンク付けを行なう手法である。これにより個体がある点に密集する ことなく、広くパレート解を形成することが可能になる。

\section{4. 単目的最適化}

\section{1 ケース設定}

本研究では次の 3 ケースを用いて $\varepsilon \mathrm{DE}$ の利用可能性を考察する。 1）Case 1: CGS を導入しないモデル。ただし CGS の排熱利用が考 慮されていない為、Table 1 の BB 容量では給湯需要を賄うことが 出来ないことから容量を $900 \mathrm{~kW}$ に増加させた。

2) Case 2: シナリオベースの運用計画。最適化手法を使うのではな く予め場合分けして定めてある運用計画に従うケースであり、現在、 経験的に運用している一般的なケースを想定する。今回は、次のよ うに設定した。i） PV は全量売電、ii）蓄電池は日中は全量需要へ供 給し、夜間(18 23 時)は電気料金の売買価格の差を利用してグリッ ドへ売電することで収益を得る方針をとる。なお、現状の制度とし ては蓄電池からグリッドへの売電は許可されていないが、 $\varepsilon \mathrm{DE}$ を評 価する際の売電ルートに関する操作変数の数の増加への対応、そし て、売電価格及び買電価格の大小関係に応じて適切な最適化が可能 か否かを判断するための試行実験としての計算条件である。 $\varepsilon \mathrm{DE}$ で 探索した場合もこのような運用になると予想されるため、Case 2 に おいても平等になるように想定した。iii）熱源機は定格 $\mathrm{COP}$ の良い ものから優先的に稼働させる方針をとり、0 7 時まで及び 18 23 時 までの電気料金が相対的に安い時間帯は TR, AHP1, AHP2, AR, HRAR の順で、日中 $(8 \sim 17$ 時 $)$ は電気料金が相対的に高いため、

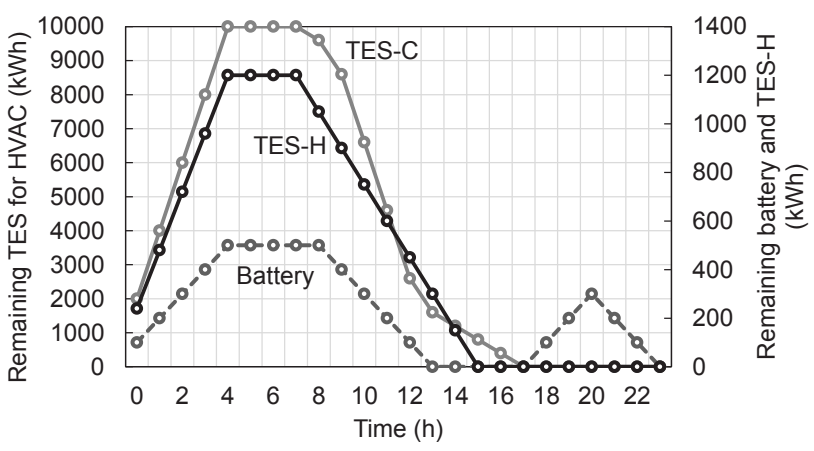

Fig. 6 Operating scenarios of a battery and TESs (Case 2)

Table 2 Results of single objective optimization

\begin{tabular}{|c|c|c|c|}
\cline { 2 - 4 } \multicolumn{1}{c|}{} & $\begin{array}{c}\text { Operating } \\
\text { costs } \\
\text { (yen/day) }\end{array}$ & $\begin{array}{c}\text { Primary energy } \\
\text { consumption } \\
\text { (MJ/day) }\end{array}$ & $\begin{array}{c}\mathrm{CO}_{2} \\
\text { emissions } \\
\left(\mathrm{kg}^{-} \mathrm{CO}_{2} / \text { day }\right.\end{array}$ \\
\hline Case 1 & 825467 & 400089 & 20485 \\
\hline Case 2 & 765444 & 393073 & 20099 \\
\hline Case 3 & 721983 & 376879 & 19284 \\
\hline
\end{tabular}

AR, HRAR, TR, AHP1, AHP2 の順で稼働させる。iv）蓄電池及び TES-C、TES-H は電気料金が最も安い 0 4 時までの間にそれぞれ 1 時間で $100 \mathrm{kWh}, 2000 \mathrm{kWh}, 240 \mathrm{kWh}$ ずつ貯め、 5 時までにエネル ギーを貯めきる。日中は電気料金の高い時間帯に最大限放エネ寸る が、13 17 時の泠房需要は熱源だけでは賄いきれないためその差を 賄う分を放熱する。TES-H は 8 15 時にかけて $150 \mathrm{kWh}$ ずつ放熱 する。残存エネルギー量の変化を Fig. 6 に示す。破線は蓄電池の残 存エネルギー量の変化を示しているが、前述したように、18 23 時 までの運転ではグリッドから蓄電池へ貯め、グリッドへ売ることで 収益を得ている。v) CGS は電力需要に合わせて発電させ、日中の不 足分は蓄電池もしくはグリッドから買電する。排熱は給湯需要へ優 先的に供給し、余った分は蓄熱槽へ供給する。日中の熱供給の不足 分は $\mathrm{BB}$ の稼働で補う。

3) Case 3： $\varepsilon \mathrm{DE}$ により最適解を探索する。

上記 3 ケースの結果を Table 2 に示す。CGS を有さない Case 1 と比較し、CGS を導入しシナリオベースの運用計画でシミュレーシ ヨンした Case 2 は目的関数である運用コストが $7.3 \%$ 削減されてお り、CGS 導入の効果は高いと言える。その Case 2 に対し、本研究 で提案する $\varepsilon \mathrm{DE} に よ る$ 運用(Case 3)では、更に $5.7 \%$ 運用コストを削 減することができた。従って、経験的なシナリオベースの運用手法 よりも本研究の最適化手法の方が結果がよく、 $\varepsilon \mathrm{DE} の$ 利用可能性は

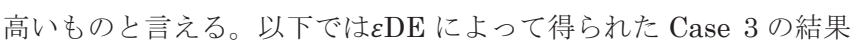
を考察する。

\section{2 一般電力系統の最適運用}

Fig. 7 に一般電力系統全体の最適運用を示す。日中の買電単価が 高い時間带に CGS が稼働しグリッドからの買電量を抑えている。 夜間は買電価格が安いこと、そして給湯需要が少ないことから CGS は稼働せずグリッドから買電している。蓄電池の稼働状況を示した Fig. 8(b)では、売電価格が買電価格を上回る早朝及び夜間は蓄電を 行なうか、もしくはグリッドへの売電が行なわれている。 


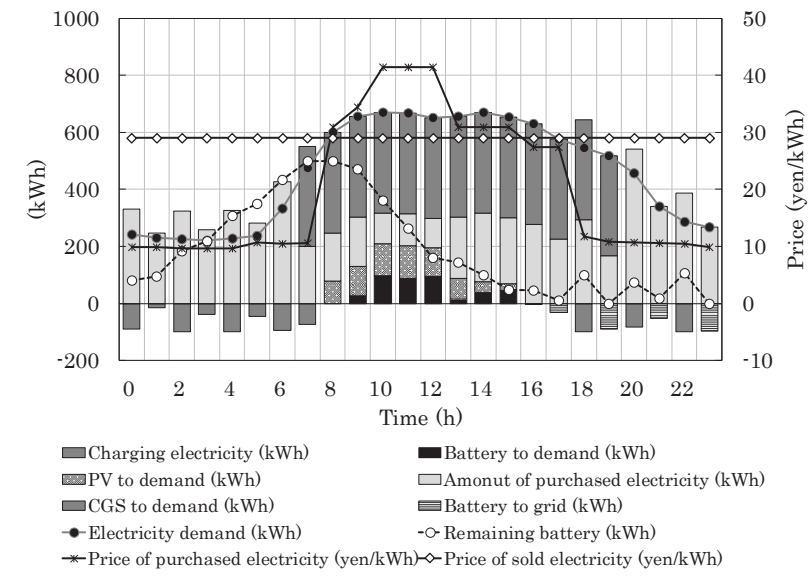

Fig. 7 Optimal operation of the electric system

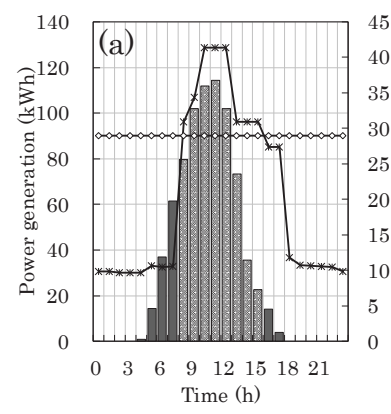

PV to demand (kWh)

$\square$ PV to grid (kWh)

* Price of purchased electricity (yen/kWh

$\nsim$ Price of sold electricity (yen/kWh)

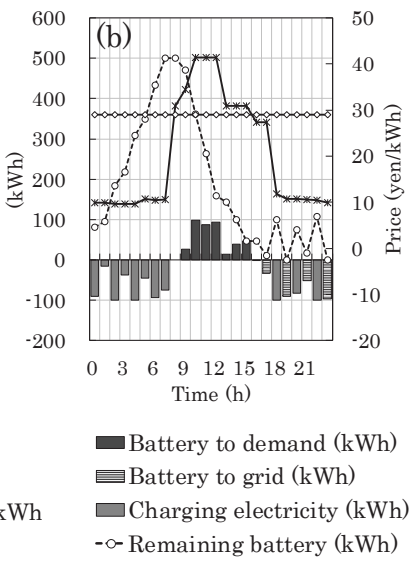

Fig. 8 Optimal operation, (a) PV, (b) Battery

PV からの発電電力の分配を示した Fig. 8(a)では、蓄電池と同様 に売電価格が買電価格を上回る早朝及び夕方に売電し、日中は全て 一般電力需要に分配している。また、PV から蓄電池へのルートは 選択されていない。これは蓄放電効率 $(81 \% /$ cycle)によりエネルギー ロスが生じることから、選択されなかったものと考えられる。

\section{3 空調システムの最適運用}

蓄熱槽は自己放熱損失 $(0.2 \% / \mathrm{h})$ 以外での熱口スは考慮していない ため、蓄電池ほど電気料金の差異の影響を受けない。ただし、蓄熱 槽が稼働すると蓄熱時には熱源が、放熱時にはポンプが稼働するこ とから、その分電力消費量が上乗せされる。従って、蓄熱槽に関し ても電気料金が安い時間帯に蓄熱し、高い時間帯に放熱することが 望ましいと考えられる。特に日中の放熱によって熱源機の負荷を低 減させている。

空調系統の運用計画を示した Fig. 9 をみると、夜間に蓄熱し、日 中に放熱していることがわかる。また、夜間は電気料金が安いため 電気系の機器(TR, AHP1, AHP2)を優先的に稼働させ蓄熱を行なっ ており、日中はガス料金が相対的に安いためガス系の機器(AR, HRAR)を優先的に稼働させ、残りを TR 及び AHP で賄う合理的な 結果が得られている。AHP1 と AHP2 の負荷配分に関しては Fig. 10 に示寸ように、同時に稼働している時間では概ね同負荷率での稼 働となっている。これは、筆者のこれまでの研究 15)によって、機器

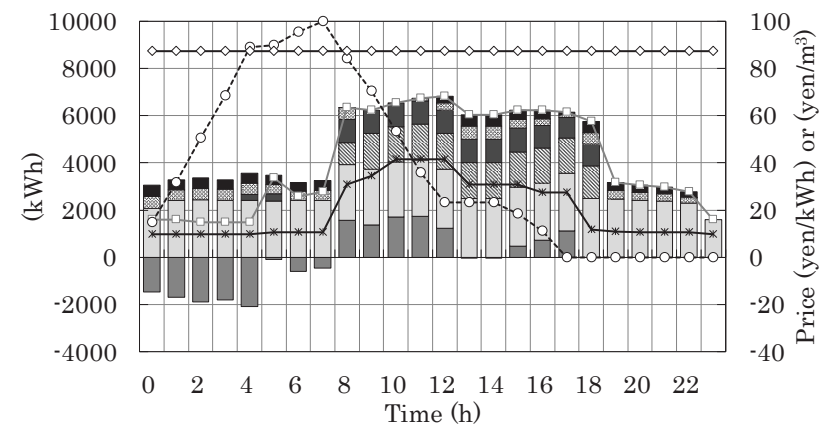

$\square$ Storing/releasing thermal energy (kWh) $\square$ Power output of TR (kWh)

बimer Power output of AR (kWh) Power output of HRAR (kWh)

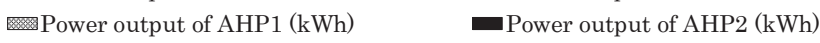

$\neg-$ Cooling demand $(\mathrm{kWh}) \quad$-o- Remaining TES (kWh)

*-Price of purchased electricity (yen $/ \mathrm{kWh}$ ) $\sim$ Price of gas $\left(\mathrm{yen} / \mathrm{m}^{3}\right.$ )

Fig. 9 Optimal operation of HVAC system

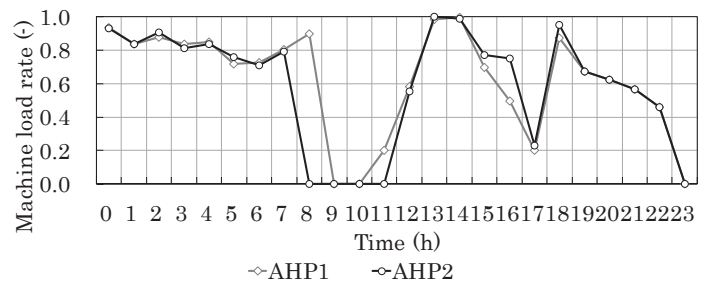

Fig. 10 Partial load rate of AHP1 and AHP2

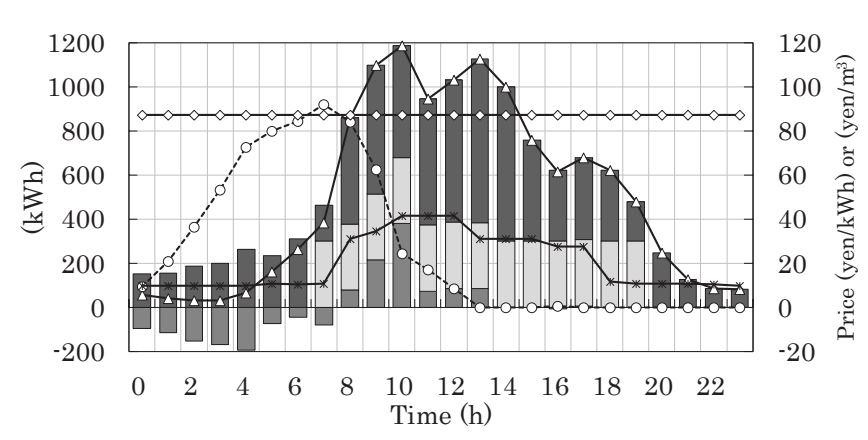

$\square$ Storing/releasing thermal energy (kWh) $\square$ CGS to HWD (kWh)

$\square$ Power output of BB (kWh) $\quad-$ Hot water demand $(\mathrm{kWh})$

$-\infty$ Remaing TES $(\mathrm{kWh}) \quad$ *Price of purchased electricity (yen/kWh)

$\prec$ Price of gas $\left(\right.$ yen $/ \mathrm{m}^{3}$ )

Fig. 11 Optimal operation of hot water system

特性が同じである熱源機器を同時に稼働させる場合、機器の容量に 因らず同負荷率で稼働させることが最も省エネになると理論的に証 明できており、今回の複雑な最適化問題においてもその理論に従う 形で最適化がなされていることを示している。

\section{4 給湯システムの最適運用}

給湯用熱源として想定した CGS 及び BB は、ガス主体の熱源で ある為、電気料金単価の差異の影響は一般電力系統や空調系統と比 べると非常に小さい。しかし、Fig. 11を見ると夜間に蓄熱し日中に 放熱する傾向にあることがわかる。これは前述のポンプ動力など非 常に小さい電力消費量であっても本研究の最適化手法において日中 には稼働を抑えようと働いた結果と考えらえる。7, 18, 19 時は電気 料金単価が相対的に低い時間ではあるが、一般電力需要及び給湯需 要が十分発生していることから CGS が稼働したほうがコストが安 
くなると判断されたと考えられる。以上によって目的関数に与える 影響が小さい要素も十分に最適化が可能なことが明らかになった。

以上の計算は一般に販売されている PC (Windows 8.1 pro (64 bit), CPU Core i7-4700 (3.40 GHz), RAM 32 GB)において MATLAB R2014b を用いて解析した。解析に要した時間は 27 分程 度であった。このように短時間での計算が可能ということは実シス テムに対しての適用が十分に可能であることを示している。

$\varepsilon \mathrm{DE}$ を含むメタヒューリスティクスは汎用性の高い探索性能を 持つ一方で確率的探索であるため必ずしも毎回同じ解が得られるわ けではない。しかし、 $\varepsilon \mathrm{DE}$ の探索性能を検討した文献 10$)$ にれば複 数回計算においても良好な結果を示していることから信頼性が高い 手法と言える。加えて、以上の考察により運用計画も妥当であるも のと判断できる。従って、NP 困難である最適化問題に対して、十 分妥当な解が短時間で得られることに $\varepsilon \mathrm{DE}$ の利点があると言える。

\section{5. 多目的最適化}

\subsection{NDS の挙動解析とパレート最適解}

本章では、一次エネルギー消費量(MJ/day) と運用コスト(yen/day) の 2 つを目的関数とし探索を行なう。個体数及び世代数は単目的最 適化時と同じである。本研究で提案する $\varepsilon \mathrm{MODE}$ の探索性能を考察 するために、本節では次の項目に注目する。

1） $\varepsilon \mathrm{DE}$ の作用： $\varphi$ 及び $\varepsilon$ の変化に見る制約条件の充足状況

2) MODEAの作用 : NDS による FRank 別個体数の推移

Fig. 12 (a)には、 $\varphi$ の最小值(Phi-min)及び $\varepsilon$ (Epsilon)の変化と各 目的関数值の最小值を示した。一次エネルギー消費量の最小值 $(\mathrm{PE}-$ $\min )$ と運用コストの最小值(OC-min)に注目すると、探索開始すぐに やや減少し、Phi-min value が Epsilon value に合わせて減少する に伴って上昇に転じる。その後、1500 世代あたりから徐々に值を減 少させ、 4000 世代手前で実行可能解が見つかったのち、目的関数值 も緩やかに減少する。これら一連の挙動は、次のように考察できる。 まず前半世代では制約条件が満たされておらず、例えば過剩な蓄熱 や放熱の下での運用コスト等を示しており、Phi-min 及び Epsilon の減少によって制約条件が満たされていくので、それに伴い目的関 数值も上昇する。制約条件が満たされて以降は、目的関数值を最小 化する方向に向かうため再びそれぞれの值が減少していく。

次に Fig. 12(b)には、各種個体数の変化を示した。実行可能解が 出現するまで(Phi-min value > 0の時)、制約逸脱度の許容值を超え る個体 $(\varphi>\varepsilon$ 個体と呼ぶ) 数は 100 個体まで接近した後、1000世代 以降緩やかに減少し、4000 世代手前で実行可能解が出現すると急減 する。その一方で実行可能個体数(Feasible)はアーカイブ個体も含 めて 180 個体程度まで急増する。次に、実行可能個体が増加した後 の挙動を考察する。ここでは、FRank が 1, 2, 3 に属する個体を示 した。FRank1 は、つまりパレート解を構成する個体数を意味して いるが、世代が進むにつれて FRank1の数が最も多くなることがわ かる。従って、パレート解を算出するにあたって、 $\varepsilon$ MODE は十分 に高い性能を有していると言える。Fig. 13 には最終的なパレート解 を示した。多くの個体がある特定の点に集中寸ることなく万遍なく パレート曲線を形成していることがわかる。
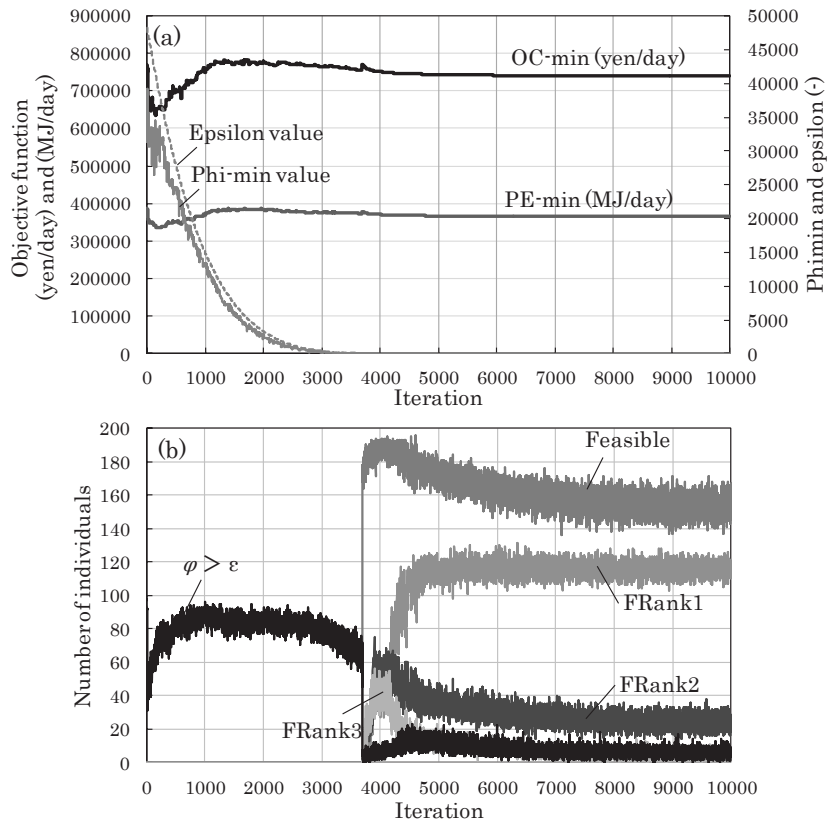

Fig. 12 Performance of $\varepsilon \mathrm{MODE}$,

(a) Objective functions, (b) Number of individuals

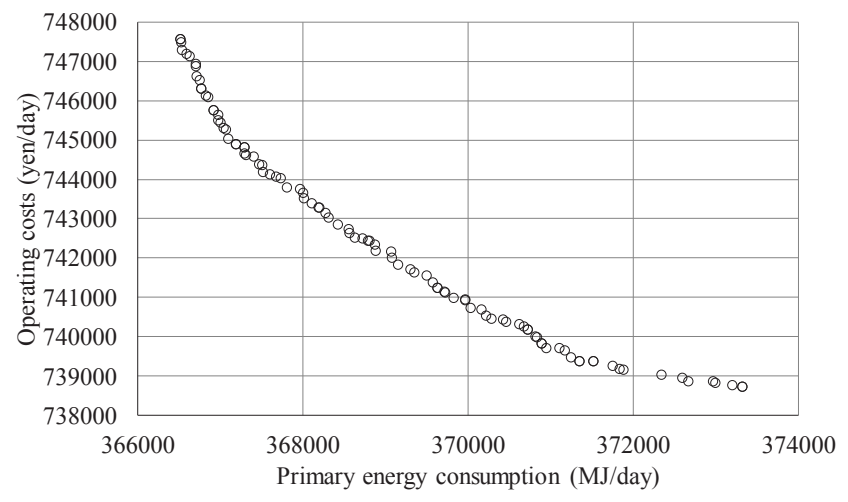

Fig. 13 Pareto-front

\section{2 最適運用の差異}

Fig. 14 には、CGS の運用に関して、第 4 章で述べた運用コスト を最小化する運用計画(Fig. 14(a)) と、一次エネルギー消費量を最小 化する運用計画(Fig. 14(b))を示す。運用コストを最小化するために は、電気料金単価が安い時間带に電気主体機器を、高い時間帯にガ ス主体機器を稼働させることが望ましく、Fig. 14(a)ではそのような 運用がなされている。また、CGS からの排熱は全て給湯需要に供給 されている。一方で、Fig. 14(b)では、日中こそ全ての排熱が給湯需 要へ供給されているが、深夜〜早朝と夜間(21 23 時)にも CGS が稼 働し、その排熱分は HRAR へも供給されている。HRAR への分配 の理由として BB と HRARの出力特性の関係性が挙げられる。Fig.3 (a)に示した通り、BB は部分負荷率 $20 \%$ を境に燃料消費特性が異な る。部分負荷率 $20 \%$ 以下の場合、どの出力であっても燃料消費率が 一定である為、 $\mathrm{BB}$ の出力が $1 \mathrm{~kW}$ 減少することによる一次エネルギ 一消費量の削減量は 0 である。 


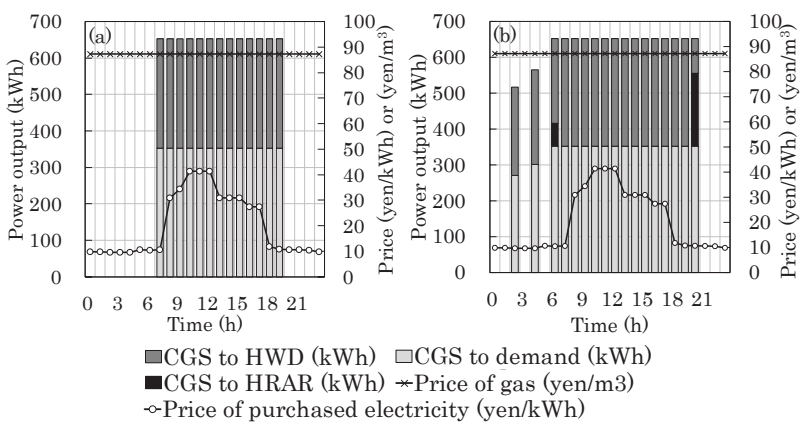

Fig. 14 Optimal operation of CGS, (a) Minimization of operating costs, (b) Minimization of primary energy consumption

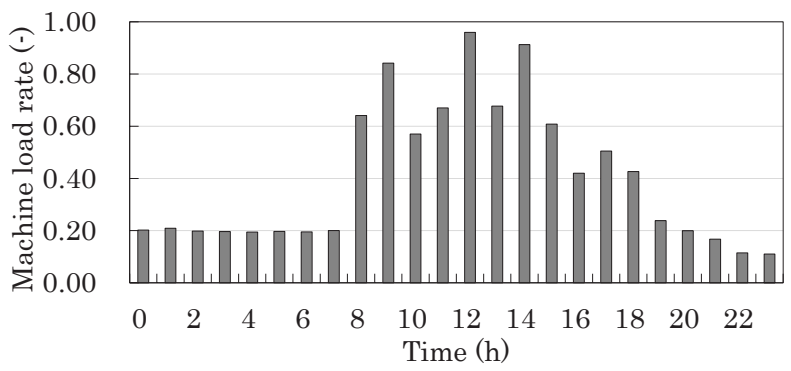

Fig. 15 Partial load rate of BB (Minimization of primary energy consumption)

一方で、HRARに $1 \mathrm{~kW}$ の排熱を供給した場合、本研究のモデルで は、外部条件で若干異なるが概ね $3.5 \mathrm{MJ}$ 抑制することが可能である ため、給湯需要ではなく HRARに排熱が供給されたと考えられる。 また、 7 時には、CGS からの排熱が HRAR と給湯需要の両方へ分 配されているが、それも前述の通り、BB の特性曲線において出力 $20 \%$ 時に特異点があることから出力を $20 \%$ に保つための運用と言え る。Fig.15 には一次エネルギー消費量最小化時の BB の運用計画を 示す。同時間帯(0 7 時)の部分負荷率が概ね 20\%で保たれているこ とがわかる。深夜時刻(21 23 時)には給湯需要が BB の定格出力 $20 \%$ 以下より少ないため、 $\mathrm{BB}$ は低負荷率での運転をせざるを得なかっ たが、0 7 時までの朝方は、給湯需要が BB の定格出力 $20 \%$ 以上に なっているため、実際には全て BB で補うことも可能である。しか し、BB の部分負荷率が $20 \%$ 以上の場合、本研究のモデルでは出力 を $1 \mathrm{~kW}$ 減少すると一次エネルギー消費量を $5.75 \mathrm{MJ}$ 削減すること が出来る。先述の HRAR の $1 \mathrm{~kW}$ 供給では $3.5 \mathrm{MJ}$ 程度の削減で あるため、深夜〜早朝は BB の出力を減らすために CGS の排熱を 給湯需要へ分配したほうがよいという選択に至ったと考察できる。

\section{6. 総括}

本研究では、近年導入が進む CGS 及び、近年注目が集まり将来 的な利活用が期待される蓄エネ設備を対象に、非線形モデリングに おいて効率的に制約条件を満たしつつ、目的関数值を最小化するた めの最適化手法(メタヒューリスティクス)を提案した。

まず前半部では、制約付き最適化手法として既往研究でその有効 性が示されていた $\varepsilon \mathrm{DE}$ を適用し、PV、CGS 及び熱源 6 台、更に、 変数間依存性が強い蓄エネ設備を 3 つ導入した複雑なエネルギーシ ステムにおいて 1 日の運用コストを最小化するための単目的最適化
を行なった。ここでは、時刻毎に異なる電気料金という条件を活か し、蓄エネ・放エネ及び電力グリッドへの売電を計画し、更に稼働 熱源の選択と負荷率の決定など幅広い項目を最適化した。また、一 般的に想定される経験的な運用計画との比較も行なったところ、 $\varepsilon \mathrm{DE}$ によって得られた結果は $5.7 \%$ 改善しており、今回のような運 用最適化問題に対して $\varepsilon \mathrm{DE}$ を適用寸る利点は十分にあると考えら れる。

次に、後半部では、多目的最適化へ拡張するために、 $\varepsilon \mathrm{DE}$ の持つ 制約条件処理能力を維持したまま、多目的最適化としてその有効性 が示されていた MODEA と組み合わせた $\varepsilon$ MODE を提案した。 $\varepsilon \mathrm{MODE}$ ではその解析挙動を詳細に考察し、その探索性能を述べた のち、十分な多様性を持つパレート解が形成されることを明らかに した。また、CGS の最適運用を軸に目的関数の違いによる最適運用 の差異に言及し、BB や HRAR 等の熱源機との複雑な組み合わせ条 件下において合理的な最適解を得ることが可能であることを明らか にした。

以上より、 $\varepsilon \mathrm{DE}$ 及び $\varepsilon \mathrm{MODE}$ は、複雑なエネルギーシステムの最 適化において、実際的な時間で十分妥当な解を得ることが可能であ ると言える。

今回の検討は発電量予測・負荷予測が外れない「完全予測型」を 扱っており、実務においては翌日の運用計画策定時に利用できる手 法である。一方で、当日の突発的な負荷変動への対応に関しては、 制御方法等より具体的な方法論が更に必要であることから、今後の 課題として検討すべき項目である。

\section{謝辞}

本論文を執筆するにあたって、東京ガス株式会社基盤技術基䃈技 術研究所熱流体チームの鍵屋慎一氏、湯浅りつ子氏に貴重なご意見 を頂戴いたしました。心より感謝したします。

\section{略称一覧}

AR: Absorption refrigerator

HRAR: Heat recovered absorption refrigerator

AHP1: Air-source heat pump 1

AHP2: Air-source heat pump 2

CGS: Co-generation system

BB: Backup boiler

TES-C: Thermal energy storage for cooling demand

TES-H: Thermal energy storage for hot water demand

B: Battery

RP: Real-time pricing

PV: Photovoltaic device

\section{参考文献}

1）伊東弘一：コージェネレーションの最適計画，産業図書, 1990

2) 石田義洋ほか 3 名：数值解析手法による複合熱源システムの機器運用の 最適化, 空気調和・衛生工学会論文集, Vol.204, pp.35-45, 2014.3

3) G. Kayo et al. : Energy sharing and matching in different combinations of buildings, CHP capacities and operation strategy, Energy and Buildings, 82, pp.685-695, 2014

4) D. Buoro et al. : Optimization of a Distributed Cogeneration System with solar district heating, Applied Energy, 124, pp.298-308, 2014 
5) T. Wakui et al. : Optimal structural design of residential cogeneration systems in consideration of their operating restrictions, Energy, 64, pp.719-733, 2014

6) 涌井徹也, 横山良平: 家庭用電熱源機器の最適機器構成計画支援ツールの 開発(エネルギー需要量の変化を考慮した複数年最適機器構成計画), 第 31 回エネルギーシステム・経済・環境コンファレンス講演論文集，10-3， pp.201-204, 2015.1

7) A.L. Facci et al. : Optimization of CHCP (combined heat power and cooling ) systems operation strategy using dynamic programming, Energy, 66, pp.387-400, 2014

8）池田伸太郎，大岡龍三:メタヒューリスティクスを用いた蓄電池・蓄熱槽・ 熱源の統合的運用最適化手法の開発, 日本建築学会環境系論文集, Vol 79, No.705, pp.957-966, 2014.11

9) T. Takahama, S. Sakai : Constrained Optimization by the $\varepsilon$ Constrained Differential Evolution with an Archive and Gradient-Based Mutation, IEEE Congress on Evolutionary Computation, pp.1-9, 2010

10) R. Mallipeddi et al. : Efficient constraint handling for optimal reactive power dispatch problems, Swarm and Evolutionary Computation, 5, pp.28-36, 2012

11) M. Ali. et al. : An efficient Differential Evolution based algorithm for solving multi-objective optimization problems, European Journal of Operational Research, 217, pp.404-416, 2012

12）空気調和・衛生工学会 : 都市ガスによるコージェネレーション評価プロ グラム：CASCADE III, 空気調和・衛生工学会, 2003.12

13）国立天文台：理科年表 平成 24 年, 丸善出版, 2011.11

14）国土交通省大臣官房官庁営繕部：LCEM ツール Ver.3.10, 2014.2

15）池田伸太郎, 長井達夫 : 遺伝的アルゴリズムとラグランジュの未定乗数 法を用いた熱源の最適化手法と運用計画チャートの開発，日本建築学会環 境系論文集, Vol.78, No.691, pp.703-709, 2013.9

16）東京ガス株式会社：ガスコージェネレーションシステムカタログ, 2013

17）建築環境・省エネルギー機構(IBEC) : BEST-P コージェネレーションシ ステム操作マニュアル, p.18, 2011.9

18）秋元孝之ほか 6 名：外皮・躯体と設備・機器の総合エネルギーシミュレ ーションツール「BEST」の開発(その 34) コージェネレーションシステム プログラムの概要, 空気調和・衛生工学会学術講演論文集, OS-22, pp.1137$1140,2008.8$

19) K. Deb et al. : A Fast and Elitist Multiobjective Genetic algorithm: NSGA-II, IEEE Transactions on Evolutionary Computation, Vol.6, No.2, 2002.4 


\title{
DEVELOPMENT OF A METAHEURISTIC NONLINEAR MULTI-OBJECTIVE OPTIMIZATION METHOD FOR OPERATING ENERGY SYSTEMS INCLUDING CGSAND ENERGY STORAGE SYSTEMS
}

\section{Shintaro IKEDA* and Ryozo OOKA**}

\author{
* Ph.D. Student, Dept. of Architecture, Graduate School of Engineering, The University of Tokyo. JSPS Research Fellow \\ ** Prof., Institute of Industrial Science, The University of Tokyo, Ph.D.
}

Co-generation systems (CGS) and energy storage equipment, such as batteries and thermal energy storage (TES), have become increasingly important recently for improving energy efficiency and for peak loads of energy systems. In addition, some heat source machines have nonlinear characteristics due to the inverter techniques used for them. However, useful they may be, these innovations have made optimal operation of modern systems more difficult compared with previous energy systems. These problems involve three aspects. 1) The number of decision variables are increased, for instance, the recovered heat connections of CGS. 2) Economic power dispatch of each heat source machine calls for nonlinear optimization. 3) Optimization of the use of energy storage equipment is parameter dependent. Therefore, we aimed to obtain a more efficient optimization method that was also more accurate than previous methods. For this purpose, we applied $\varepsilon \mathrm{DE}$ (epsilon constrained differential evolution) for single objective optimization problem to minimize operating costs. Moreover, we proposed $\varepsilon$ MODE (epsilon constrained multi-objective differential evolution) to solve the complex trade-off problem (e.g. operating costs vs primary energy consumption).

For the minimization of operating costs, $\varepsilon \mathrm{DE}$ uncovered that when the price of purchased electricity is higher than that of sold electricity, the electricity stored in batteries should be discharged and sold to the grid. On the other hand, battery power should be used to satisfy electric demand when the price of purchased electricity is lower than that of sold electricity. CGS were not operated at night and in early morning because, during those times, the operating costs of electrical machines (e.g., centrifugal refrigerator) was lower than that of the gasification machines (e.g., CGS). On the other hand, during the day time, CGS generated power and recovered heat was distributed not to a heat-recovered absorption refrigerator (HRAR) but to satisfy hot-water demand.

For the multi-objective optimization, $\varepsilon$ MODE could carry out a lot of non-dominated solutions without concentrating on a certain position and generating dominated solutions. Although the CGS did not work at the night time and early morning to achieve optimal operation of CGS (in terms of minimization of operating costs), the CGS worked within each time interval, in terms of minimization of primary energy consumption. The reason is that the recovered heat was distributed to satisfy hot-water demand in order to provide a partial-load rate of 20\% for the back-up boiler (BB) during early morning. This is because this partial load rate was the most efficient.

Therefore, $\varepsilon D E$ and $\varepsilon$ MODE could be used to carry out optimal solutions in practical amounts of time, even if the problem involved a lot of decision variables that were nonlinear. 